\title{
The non-NMDA glutamate receptor antagonist GYKI 52466 counteracts locomotor stimulation and anticataleptic activity induced by the NMDA antagonist dizocilpine
}

\author{
Wolfgang Hauber and Ragna Andersen \\ Biologisches Institut, Abteilung Tierphysiologie, Universität Stuttgart, Pfaffenwaldring 57, D-70550 Stuttgart, Germany
}

Received April 26, 1993/Accepted August 17, 1993

\begin{abstract}
Summary. The effects of the non-NMDA glutamate receptor antagonist GYKI 52466 (2.4 and $4.8 \mathrm{mg} / \mathrm{kg}$, i.p.) on spontaneous locomotor activity and haloperidol-induced catalepsy $(0.5 \mathrm{mg} / \mathrm{kg}$, i.p.) were assessed in naive rats and in rats pretreated with the NMDA antagonist dizocilpine $(0.08 \mathrm{mg} / \mathrm{kg}$, i. p.). GYKI 52466 given alone did not alter locomotor activity and haloperidol-induced catalepsy, but significantly antagonized the dizocilpineinduced locomotor stimulation and counteracted the anti-cataleptic effects of dizocilpine on haloperidol-induced catalepsy. Thus blockade of non-NMDA glutamate receptors antagonized the behavioural stimulant effects of a NMDA receptor blockade.
\end{abstract}

Key words: NMDA receptors - Non-NMDA receptors Dizocilpine - GYKI 52466 - Locomotion Haloperidol-induced catalepsy - Rat

\section{Introduction}

The synaptic responses elicited by excitatory amino acids (EAA) are mediated by different receptor subtypes distinguished according to their preferential agonists as $\mathrm{N}$ methyl-D-aspartate (NMDA)-, kainate (KA)-, $\alpha$-amino-3-hydroxy-5-methyl-4-isoxazole propionate (AMPA)preferring receptors and the metabotropic 1-aminocyclopentane-transdicarboxylate (ACPD) receptor (Monaghan et al. 1989). The behavioural pharmacology of AMPA and KA subtypes of glutamate receptors, termed here collectively as non-NMDA receptors, is rarely investigated at present. Furthermore little is known about the interactions of non-NMDA receptors with NMDA receptors or other transmitter systems, e.g. the dopaminergic system, in behavioural models. The quinoxalinedione NBQX (2,3-dihydroxy-6-nitro-7-sulfamoyl-benzo(F)-quionoxaline) (Honoré et al. 1988) and the 2,3-benzodiazepine GYKI 52466 (Tarnawa et al. 1989) are selective

Correspondence to: W. Hauber at the above address antagonists of non-NMDA receptors (Honoré 1991; Tarnawa et al. 1990; Quardouz and Durand 1991). Systemic administration of NBQX to drug-naive rats had no or even a weak suppressive effect on spontaneous motor behaviour (Klockgether et al. 1991). In animal models or Parkinson's disease (PD), NBQX potentiated the antiparkinson activity of L-DOPA but had no effect or even increased hypoactivity when given alone (Klockgether et al. 1991; Löschmann et al. 1991). By contrast, systemic administration of NMDA antagonists produced a marked behavioural stimulation in drug-naive rats (Bubser et al. 1992; Hoffman 1992; Tiedtke et al. 1990) and reversed parkinsonian symptoms in rodent models of PD (Carlsson and Carlsson 1989; Schmidt and Bubser 1989; Hauber and Schmidt 1990). The effects of NMDA and non-NMDA antagonists are mediated by complex actions within the basal ganglia as shown by studies using local drug administration (see Schmidt et al. 1992 for review). On the basis of these findings a blockade of NMDA receptors (Carlsson and Carlsson 1989; Schmidt and Bubser 1989) or AMPA receptors (Klockgether et al. 1991; Löschmann et al. 1991) was suggested to provide a new strategy for the treatment of PD.

In the present study we investigated the effects of a blockade of non-NMDA receptors on spontaneous locomotor activity and on haloperidol-induced catalepsy in rats. Neuroleptic-induced catalepsy may be considered as a model of PD because of similarities with the parkinsonian symptoms akinesia and rigidity (Sanberg et al. 1988). We further examined the effects of a simultaneous blockade of NMDA and non-NMDA receptors in these behavioural tests. The non-NMDA antagonist GYKI 52466 and dizocilpine, a potent noncompetitive NMDA antagonist, were used to investigate the contribution of these glutamate receptor subtypes to the expression of motor behaviour.

\section{Materials and methods}

Animals. Male Sprague-Dawley rats (Interfauna, Tuttlingen, Germany) were used weighing $235-250 \mathrm{~g}$ at the start of the experiment. They were 
housed in groups of four or five per cage with free access to water. Food was restricted to $12 \mathrm{~g}$ standard laboratory maintenance diet (Altromin, Lage, Germany) per animal and day. Rats were housed in a colony room maintained at $22 \pm 3^{\circ} \mathrm{C}$ on a 12:12 light-dark cycle (lights on $06.00 \mathrm{~h}$ ).

Behavioural procedure. Spontaneous locomotor activity was assessed in an open field $(69 \times 69 \mathrm{~cm})$ divided by lines in 9 squares of equal size. The open field box was opaque and illuminated by 4 red light bulbs $(20 \mathrm{~W})$; back ground noise was masked by a fan. An animal was placed individually for $10 \mathrm{~min}$ into the open field. Locomotor activity was monitored by video recording and evaluated by counting the number of line crossings during the observation period.

Catalepsy was measured 30 and $60 \mathrm{~min}$ after injection of haloperidol in three different tests performed in the following order (ScheelKrüger 1983):

I. Bar: both forelegs were placed on a horizontal bar $(9 \mathrm{~cm}$ above the surface); II. Podium: one foreleg was placed on a podium ( $3 \mathrm{~cm}$ high); III. Grid: an animal was clinged to a vertical wire grid.

The latency from paw placement until the first movement of one of the respective paws (termed here as descent latency) was measured (cutoff: $180 \mathrm{~s}$ ).

Drugs. Dizocilpine ([+]-5-methyl-10,11-dihydro-5H-dibenzo(a,d)cyclohepten-5,10-imine) (Biotrend, Köln, Germany) and haloperidol (Janssen, Neuss, Germany) were dissolved in physiological saline, respectively. GYKI 52466 (1-(4-aminophenyl)-4-methyl-7,8-methylendioxy-5H-2,3-benzodiazepine $\mathrm{HCl}$ ) obtained from Dr. I. Tarnawa (Inst. Drug Research, Hungary) was dissolved in destilled water. Dizocilpine $(0.08 \mathrm{mg} / \mathrm{kg}$, i.p.), GYKI $52466(2.4$ and $4.8 \mathrm{mg} / \mathrm{kg}$, i.p. $)$ and haloperidol $(0.5 \mathrm{mg} / \mathrm{kg}$, i.p.) were administered alone or in combination in a maximum volume of $1 \mathrm{ml} 30 \mathrm{~min}$ before the individual onset of the behavioral test. Controls in the open field and catalepsy experiment received intraperitoneal injections of saline $(1 \mathrm{ml} / \mathrm{kg})$.

Statistical analysis. Data are presented as means with standard errors of the means $( \pm$ SEM). The open field data were submitted to an analysis of variance (ANOVA) with treatment as factor followed by a Tukey-test for comparing means of treatment groups. The catalepsy data were submitted to a Mann-Whitney U-test (two-tailed). Differences were considered to be significant if the P-value is less then 0.05 .

\section{Results}

\section{Open field}

A one-way ANOVA with treatment as factor followed by a Tukey protected $t$-test revealed that dizocilpine $(0.08 \mathrm{mg} / \mathrm{kg}$, i.p.) given alone induced a significant increase of spontaneous locomotor activity (ANOVA: $P<0.0005$; dizocilpine versus saline: $t=-4.01 ; P<0.01)$. Administration of GYKI (2.4 and $4.8 \mathrm{mg} / \mathrm{kg}$, i.p.) did not significantly alter spontaneous locomotor activity (Fig. 1).

Administration of GYKI $52466(2.4$ and $4.8 \mathrm{mg} / \mathrm{kg}$, i.p.) to animals pretreated with dizocilpine $(0.08 \mathrm{mg} / \mathrm{kg}$, i.p.) significantly antagonized dizocilpine-induced locomotor hyperactivity as shown in Fig. 1 (ANOVA $P<0.0001$; dizocilpine versus dizocilpine+GYKI 52466 $2.4 \mathrm{mg} / \mathrm{kg}$ : $\quad t=5.3, \quad P<0.01$; dizocilpine versus dizocilpine plus GYKI $4.8 \mathrm{mg} / \mathrm{kg}: t=3.8, P<0.01$ ). Line crossings of all treatment groups are significantly different from the saline group (saline versus dizocilpine: $t=-8.1 ; P<0.01$; saline versus dizocilpine plus GYKI $524662.4 \mathrm{mg} / \mathrm{kg}$ : $t=-2.7 ; \quad P<0.05 ; \quad$ saline versus dizocilpine plus GYKI $524664.8 \mathrm{mg} / \mathrm{kg}: t=-4.3$; $P<0.01$ ).
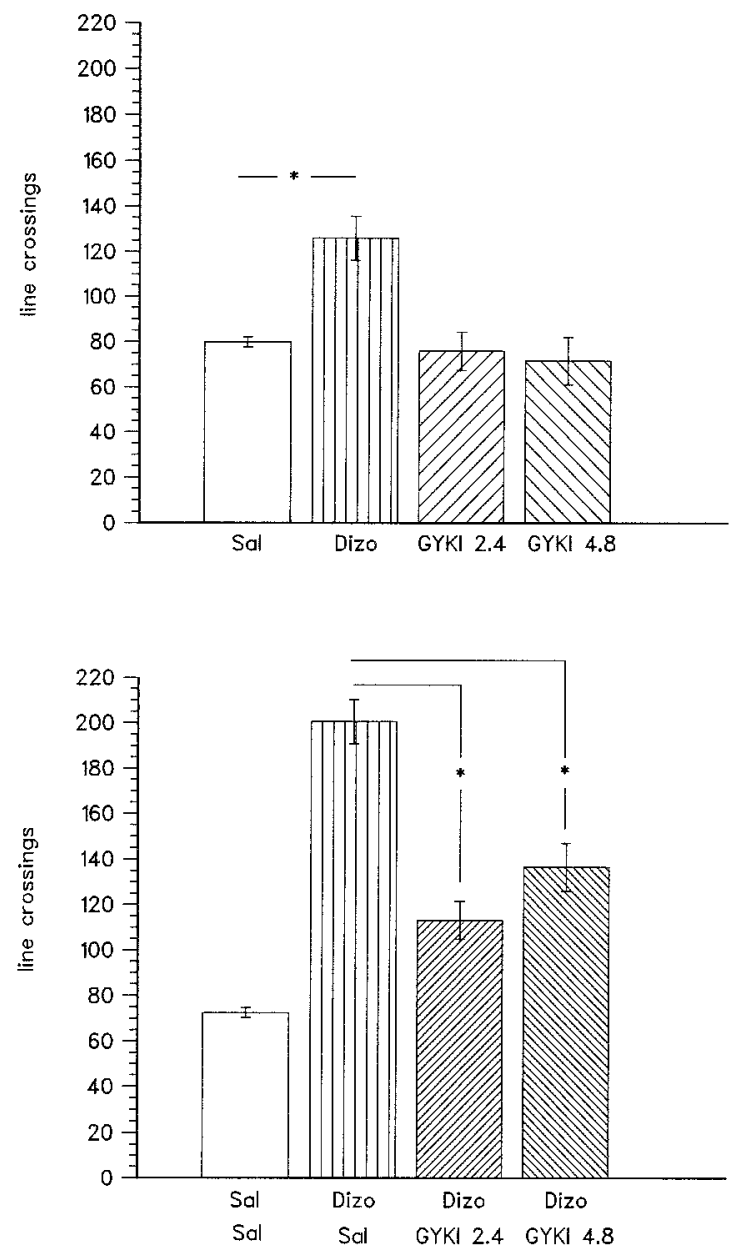

Fig. 1. Mean number of line crossings $( \pm S E M)$ in an open field. Treatment groups received intraperitoneal injections of saline $(1 \mathrm{ml} / \mathrm{kg}$; $n=6)$, dizocilpine $(0.08 \mathrm{mg} / \mathrm{kg}, n=6)$ or GYKI $52466(2.4 \mathrm{mg} / \mathrm{kg}$, $n=6$ and $4.8 \mathrm{mg} / \mathrm{kg}, n=6$ ) (top) or intraperitoneal coinjections of dizocilpine $(0.8 \mathrm{mg} / \mathrm{kg})$ plus saline $(1 \mathrm{ml} / \mathrm{kg}, n=6)$ or dizocilpine $(0.08 \mathrm{mg} / \mathrm{kg})$ plus GYKI $52466(2.4 \mathrm{mg} / \mathrm{kg}, n=6$ and $4.8 \mathrm{mg} / \mathrm{kg}$, $n=6)$. Rats with saline injections $(1 \mathrm{ml} / \mathrm{kg}, n=6)$ served as controls (bottom). ${ }^{*} P<0.01$ (ANOVA followed by Tukey's test)

\section{Catalepsy}

Dizocilpine $(0.08 \mathrm{mg} / \mathrm{kg}$, i.p. $)$ given alone exerted a significant anti-cataleptic effect (haloperidol versus haloperidol plus dizocilpine: $P<0.007$ for each test and measurement).

As shown in Fig. 2 the anti-cataleptic activity of dizocilpine was completely reversed by coadministration of GYKI $52466(2.4 \mathrm{mg} / \mathrm{kg})$ (haloperidol plus dizocilpine versus haloperidol plus dizocilpine plus GYKI: $P<0.01$ for each test and measurement). Results obtained in animals treated with haloperidol plus dizocilpine plus GYKI were not statistically different from animals treated only with haloperidol $(P>0.05$ for each test and measurement). The higher dose of GYKI $(4.8 \mathrm{mg} / \mathrm{kg}$, i.p.) in combination with haloperidol and dizocilpine exerted a strong muscle relaxant effect. In more then $50 \%$ of the animals it was impossible to perform the grid and bar test because animals slipped away due to muscle relaxation. In the remaining animals there was a clear tendency for a reversal of the anti-cataleptic activity of dizocilpine (da- 


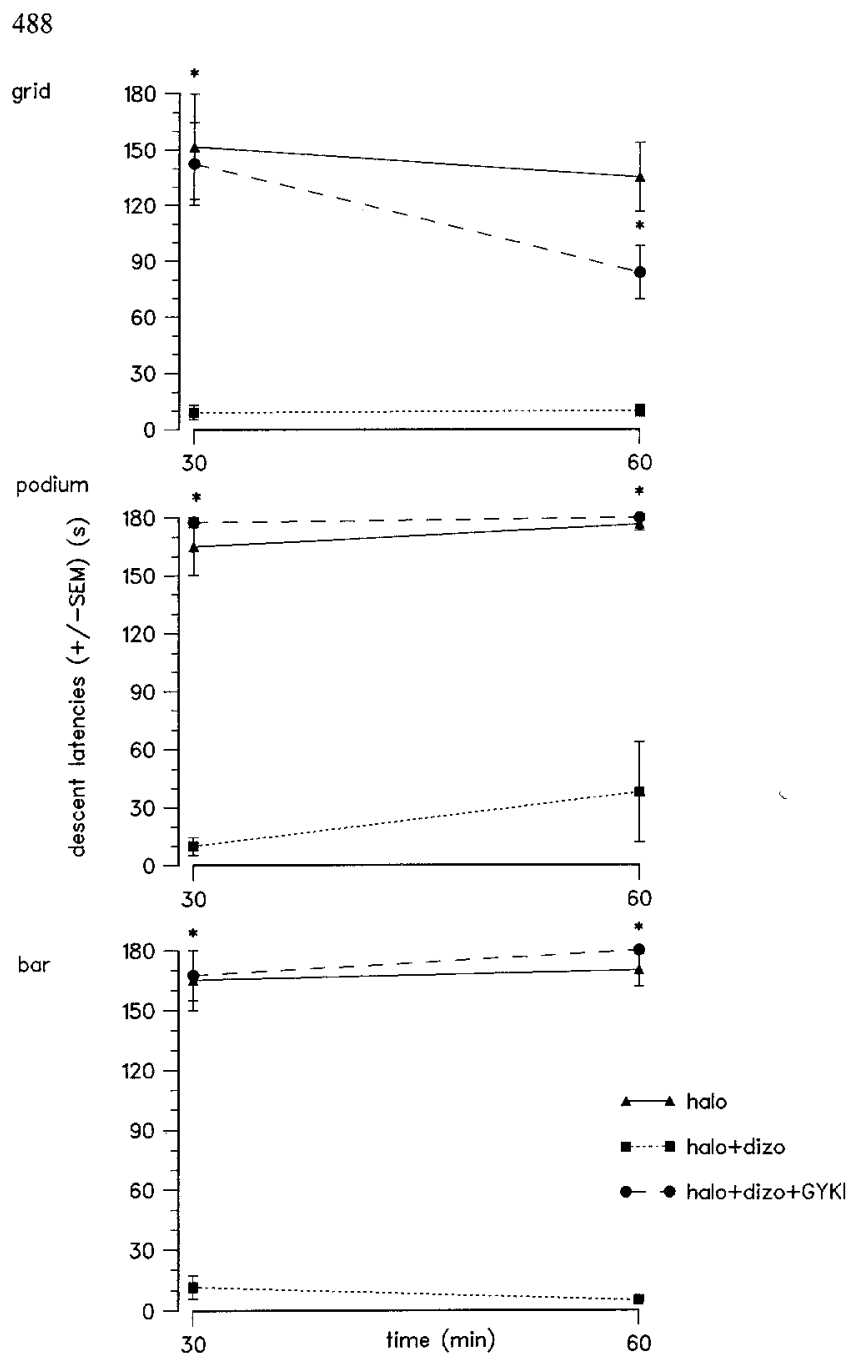

Fig. 2. Mean descent latencies ( \pm SEM) in the catalepsy test. Treatment groups received intraperitoneal injections of haloperidol $(0.5 \mathrm{mg} / \mathrm{kg})$ plus saline $(1 \mathrm{ml} / \mathrm{kg}, n=6)$, haloperidol $(0.5 \mathrm{mg} / \mathrm{kg})$ plus dizocilpine $(0.08 \mathrm{mg} / \mathrm{kg})$ plus saline $(1 \mathrm{ml} / \mathrm{kg}, n=6)$ or haloperidol $(0.5 \mathrm{mg} / \mathrm{kg})$ plus dizocilpine $(0.08 \mathrm{mg} / \mathrm{kg})$ plus GYKI $52466(2.4 \mathrm{mg} / \mathrm{kg}, n=5)$ ${ }^{*} P<0.01$ haloperidol plus dizocipline versus haloperidol plus dizocilpine plus GYKI (Mann-Whitney U-test, two-tailed)

ta not shown). GYKI 52466 given alone in a dose shown to potently reverse dizocilpine-induced anticataleptic effect did not alter the degree of haloperidol-induced catalepsy: Mean descent latencies of animals $(n=6)$ with injections of GYKI $52466(2.4 \mathrm{mg} / \mathrm{kg}$, i.p.) plus haloperidol $(0.5 \mathrm{mg} / \mathrm{kg}$, i.p.) and of animals $(n=5)$ with injections of saline $(1 \mathrm{mg} / \mathrm{kg}$, i.p.) plus haloperidol $(0.5 \mathrm{mg} / \mathrm{kg}$, i.p.) were not different 30 and 60 min after drug administration $(P>0.05$ for each test and measurement, MannWhitney U-test (data not shown).

\section{Discussion}

Systemic administration of the non-NMDA antagonist GYKI 52466 in doses shown to be anticonvulsant and without adverse effects in rodent models of epilepsy (Smith et al. 1991) had not effect on spontaneous locomotor activity. Furthermore GYKI 52466 given alone did not alter the degree of haloperidol-induced catalepsy.
However, coadministration of GYKI 52466 significantly antagonized dizocilpine-induced locomotor hyperactivity. In addition, coadministration of GYKI 52466 significantly reversed the anti-cataleptic effect of dizocilpine.

Thus a blockade of non-NMDA receptors potently reversed the stimulating motor effects induced by a noncompetitive blockade of NMDA receptors, but did not significantly change motor activity when given alone.

The finding that administration of a non-NMDA antagonist did not change spontaneous motor activity confirms previous studies showing that NBQX had no effect on or reduced the locomotor activity in drug-naive rats (Klockgether et al. 1991) and did not affect motor behaviour in normal monkeys (Greenamyre 1992). In rats with unilateral nigral 6-hydroxydopamine lesions or MPTPtreated monkeys, systemic administration of NBQX reduced rotational behaviour and locomotor activity (Löschmann et al. 1991). In addition, NBQX did not improve akinesia, but suppressed muscular rigidity in monoamine-depleted rats (Klockgether et al. 1991) and did not antagonize raclopride-induced catalepsy (Papa et al. 1993). These findings are congruent with the present data showing that GYKI given alone did not antagonize haloperidol-induced catalepsy.

The effects of NBQX in monoamine-depleted rats, in rats with nigral 6-hydroxydopamine lesions and in MPTP-treated monkeys and the present findings on GYKI 52466 in the haloperidol-induced catalepsy argue against the view that non-NMDA antagonists given alone are useful in the treatment of PD.

Why systemically administered non-NMDA antagonists did - in contrast to local infusion into basal ganglia nuclei- not alter motor activity remains unclear and cannot be determined by the present study using systemic administrations. Local administration of non-NMDA antagonists into basal ganglia output nuclei produced marked anti-akinetic effects in animals with parkinsonian symptoms (Brotchie et al. 1991, 1992; Graham et al. 1990; Klockgether et al. 1991). It was suggested that these effects are brought about by a blockade of non-NMDA receptors in basal ganglia output nuclei which are overactive in this condition. On the other hand, the density of glutamate receptor subtypes is relatively low in nonstriatal basal ganglia nuclei. For this reason the efficacy of modifying the activity of non-striatal basal ganglia nuclei by systemic administration of EAA antagonists appears to be limited (Albin et al. 1992). Studies on the role of non-NMDA receptors in basal ganglia nuclei with high AMPA/KA receptors densities, i.e. the caudate-putamen and the nucleus accumbens showed that local infusion of kainate or quisqualate into these structures induced a behavioural stimulation (Imperato et al. 1990). In addition, local infusion of NBQX into the dorsal striatum did not antagonize akinesia in reserpinized rats (Klockgether et al. 1991). Therefore non-NMDA receptors in the striatum and the nucleus accumbens seem to mediate opposite behavioural effects as non-NMDA receptors in basal ganglia output nuclei which is difficult to explain with regard to the proposed basal ganglia pathways. Thus the contribution of non-NMDA receptors in relevant basal ganglia nuclei to the behavioural effects of systemically 
administered non-NMDA antagonists remain obscure at present. The present study further revealed that the nonNMDA antagonist GYKI 52466 significantly antagonized the locomotor stimulation induced by the noncompetitive NMDA antagonist dizocilpine and abolished the anticataleptic activity of dizocilpine. The findings on dizocilpine-induced locomotor stimulation and anticataleptic activity replicate similar observations in a number of previous reports (e.g. Hauber and Schmidt 1990; Hoffman 1992; Schmidt and Bubser 1989; Tiedtke et al. 1990). The dizocilpine-induced anti-cataleptic activity was potently antagonized by the lower dose of GYKI 52466, while the higher dose of GYKI exerted in this test a strong muscle relaxant activity. Although GYKI 52466 was found to have central muscle relaxant properties (Tarnawa et al. 1989, 1990), no muscle relaxation was observed when GYKI 52466 had been given alone in the doses used here. Thus muscle relaxation seen in the catalepsy test seems to be due to the combined administration of the high dose of GYKI 52466 together with dizocilpine and haloperidol.

Again the mechanisms and sites of action in the basal ganglia through which a non-NMDA receptor antagonist can inhibit the motor stimulating effects of a NMDA receptor blockade are unknown. The striatum is the main input structure of the basal ganglia and receives glutamatergic inputs from the neocortex. These cortical inputs are transmitted via a direct and an indirect striatothalamic route back to the cortex. The direct pathway encompasses neurons from the striatum to the output nuclei of the basal ganglia, namely the substantia nigra and the entopeduncular nucleus (the rat homologue of the medial pallidal segment). The indirect pathway encompasses neurons from the striatum to the globus pallidus (the rat homologue of the lateral pallidal segment) and via the subthalamic nucleus to the basal ganglia output nuclei (see Albin et al. 1989 for review). It was recently proposed that the direct and indirect pathway are distinct with regard to the tonicity of their respective glutamatergic inputs (Svensson et al. 1992). According to this hypothesis the direct pathway which is behaviourally activating receives a low glutamatergic input from cortical-striatal neurons. By contrast the indirect loop is behaviourally suppressive. Glutamatergic cortical neurons impinging on striatal neurons of the indirect pathway were suggested to have a higher activity as compared to cortico-striatal neurons impinging on the direct pathway (Svensson et al. 1992). Thus dizocilpine preferentially blocks striatal neurons which are part of the indirect pathway because the higher glutamatergic tonicity enhances the binding probability of the open channel blocker dizocilpine. The dizocilpine binding site is within the NMDA receptor associated ion channel and therefore binding of dizocilpine depends on channel activation by NMDA receptor stimulation (see Chen et al. 1992 for references). The dizocilpine-induced selective blockade of the behavioural suppressive indirect pathway leads then to motor stimulation (Svensson et al. 1992). Thus a decreased glutamatergic tonicity in the indirect pathway would reduce use-dependent binding and behavioural effects of the noncompetitive NMDA antagonist dizocilpine. Indeed
GYKI 52466 was found to reduce extracellular glutamate in the striatum and cortex induced by ischemia in rats. This effect is probably due to an inhibition of glutamate release via presynaptic kainate receptors (Arvin et al. 1992). A decreased glutamate release could explain why GYKI 52466 reversed dizocilpine-induced effects. However it is not known whether GYKI 52466 also reduces glutamate release in non-ischemic conditions. Furthermore a GYKI 52466-induced reduction of glutamate release should counteract haloperidol-induced catalepsy in a similar way as shown for frontal decortication (Yoshida et al. 1991). This was, however, not observed when GYKI 52466 was given alone, thus making this mechanism unlikely.

An alternative explanation is that GYKI 52466 blocks postsynaptic non-NMDA receptors on striatal neurons which are part of the indirect loop. A blockade of nonNMDA receptors reduces depolarisation which is in turn a prerequisite for the voltage-sensitive activation of NMDA receptor associated channels and binding of dizocilpine (see Headley and Grillner 1991 for review). Furthermore, interactions of NMDA and non-NMDA receptors in the indirect pathway downstream of the striatum may contribute the GYKI 52466-induced reversal of the dizocilpine effects. However, the contribution of non-striatal EAA receptor subtypes appears to be limited due to the low receptor density in non-striatal basal ganglia nuclei (see above).

In summary, systemic administration of a nonNMDA antagonist reversed the stimulating motor effects induced by a noncompetitive NMDA antagonist. This interaction is likely to take place within the basal ganglia by mechanisms which remain to be detected by studies with local drug administration. The present study does not support the view of a therapeutic potential for nonNMDA antagonists in the treatment of PD when given alone.

Acknowledgements. The excellent technical assistance of A. Hoffmann and S. Schmidt is gratefully acknowledged. Thanks are given to Dr. I. Tarnawa (Inst. Drug Research, Hungary) for kindly providing GYKI 52466.

\section{References}

Albin RL, Young AB, Penney JB (1989) The functional anatomy of basal ganglia disorders. Trends Neurosci 12:366-375

Albin RL, Makowiec RL, Hollingsworth ZR, Dure IV LS, Penney JB, Young AB (1992) Excitatory amino acid binding sites in the basal ganglia of the rat: A quantitative autoradiographic study. Neuroscience 46:35-48

Arvin B, Moncada C, Le Peillet E, Chapman A, Meldrum BS (1992) GYKI 52466 blocks the increase in extracellular glutamate induced by ischaemia. Neuro Rep 3:235-238

Brotchie JM, Mitchell IJ, Sambrook MA, Crossman AR (1991) Alleviation of Parkinsonism by antagonism of excitatory amino acid transmission in the medial segment of the globus pallidus in rat and primate. Movement Dis 6:133-138

Brotchie JM, Mitchell IJ, Crossman AR (1992) The NMDA receptor-associated glycine site: A target for symptomatic treatment of Parkinson's disease? Eur J Neurosci [Suppl] 5:237 
Bubser M, Keseberg U, Notz PK, Schmidt WJ (1992) Differential behavioural and neurochemical effects of competitive and noncompetitive NMDA receptor antagonists in rats. Eur J Pharmacol 229:75-82

Carlsson M, Carlsson A (1989) The NMDA antagonist MK-801 causes marked locomotor stimulation in monoamine depleted mice. $\mathrm{J}$ Neural Transm 75:221-226

Chen H-SV, Pellegrini JW, Aggarwal SK, Lei SZ, Warach S, Jensen FE, Lipton SA (1992) Open-channel block of N-methyl-D-aspartate (NMDA) responses by memantine: Therapeutic advantage against NMDA receptor-mediated neurotoxicity. J Neurosci 12:4427-4436

Graham WC, Robertson RG, Sambrook MA, Crossman AR (1990) Injection of excitatory amino acid antagonists into the medial pallidal segment of a 1-methyl-4-phenyl-1,2,3,6-tetrahydropyridine (MPTP) treated primate reverses motor symptoms of parkinsonism. Life Sci $47: 91-97$

Greenamyre JT (1992) Actions of glutamate antagonists in the MPTP primate model of Parkinson's disease. Eur J Neurosci [Suppl] 5: p 238

Hauber W, Schmidt WJ (1990) The NMDA antagonist dizocilpine (MK-801) reverses haloperidol-induced movement initiation deficits. Behav Brain Res 41:161-166

Headley PM, Grillner S (1991) Excitatory amino acids and synaptic transmission: the evidence for a physiological function. In: Lodge $\mathrm{D}$, Collingridge $\mathrm{G}$ (eds) The pharmacology of excitatory amino acids. Trends Pharmacol Sci (Special Report), pp 30-36

Hoffman DC (1992) Typical and atypical neuroleptics antagonize MK-801-induced locomotion and stereotypy in rats. J Neural Transm 89:1-10

Honoré T (1991) Inhibitors of kainate and AMPA ionophore receptors. In: Meldrum BS (ed) Excitatory Amino Acid Antagonists, Blackwell Scientific, Oxford pp 180-194

Honoré T, Davies SN, Drejer J, Fletcher EJ, Jakobsen P, Lodge D, Nielsen FE (1988) Quinoxalinediones: Potent competitive nonNMDA glutamate receptor antagonists. Science 241:701

Imperato A, Honoré T, Jensen LH (1990) Dopamine release in the nucleus caudatus and in the nucleus accumbens is under glutamatergic control through non-NMDA receptors: A study in freely-moving rats. Brain Res 530:223-228

Klockgether T, Turski L, Honoré T, Zhang Z, Gash DM, Kurlan R, Greenamyre JT (1991) The AMPA receptor antagonist NBQX has antiparkinsonian effects in monoamine-depleted rats and MPTPtreated monkeys. Ann Neurol 30:717-723

Löschmann P-A, Lange KW, Kunow M, Rettig K-J, Jähnig P, Honoré T, Turski L, Wachtel H, Jenner P, Marsden CD (1991) Synergism of the AMPA-antagonist NBQX and the NMDA-antagonist CPP with L-Dopa in models of Parkinson's disease. I Neural Transm $3: 203-213$

Monaghan DT, Bridges RJ, Cotman CW (1989) The excitatory amino acid receptors: Their classes, pharmacology, and distinct properties in the function of the central nervous system. Ann Rev Pharmacol Toxicol 29:365-402

Quardouz M, Durand J (1991) GYKI 52466 antagonizes glutamate responses but not NMDA and kainate responses in rat abducens motoneurones, Neurosci Lett 125:5-8

Papa SM, Engber TM, Boldry RC, Chase TN (1993) Opposite effects of NMDA and AMPA receptor blockade on catalepsy induced by dopamine receptor antagonists. Eur J Pharmacol 232:247-253

Sanberg PR, Bunsey MD, Giordano M, Norman AB (1988) The catalepsy test: its ups and downs. Behav Neurosci 102:748-759

Scheel-Krüger J (1983) The GABA receptor and animal behavior. In: Enna SJ (ed) The GABA receptors. Clifton NJ, The Humana Press, pp 215-256

Schmidt WJ, Bubser M (1989) Anticataleptic effects of the N-methyl-D-aspartate antagonist MK-801 in rats. Pharmacol Biochem Behav 32:621-623

Schmidt WJ, Bubser M, Hauber W (1992) Behavioural pharmacology of glutamate in the basal ganglia. J Neural Transm 38:65-89

Smith SE, Dürmüller N, Meldrum BS (1991) The Non-N-methyl-D-aspartate receptor antagonists, GYKI 52466 and NBQX are anticonvulsant in two animal models of reflex epilepsy. Eur J Pharmacol 201:179-183

Svensson A, Carlsson A, Carlsson ML (1992) Differential locomtor interactions between dopamine D1/D2 receptor agonists and the NMDA antagonist dizocilpine in monoamine-depleted mice. $\mathbf{J}$ Neural Transm 90:199-217

Tarnawa I, Farkas S, Berzsenyi P, Pataki A, Andrasi F (1989) Electrophysiological studies with a 2,3-benzodiazepine muscle relaxant: GYKI 52466. Eur J Pharmacol 167:193

Tarnawa I, Engberg I, Flatman JA (1990) GYKI 52466, an inhibitor of spinal reflexes is a potent quisqualate antagonist. In: Lubec $G$, Rosenthal GA (eds) Amino acids. Chemistry, Biology, and Medicine, Escom, Leiden, pp 538-546

Tiedke PI, Bischoff C, Schmidt WJ (1990) MK-801-induced stereotypy and its antagonism by neuroleptic drugs. J Neural Transm $81: 173-182$

Yoshida Y, Ono T, Kizu A, Fukushima R, Miyagishi T (1991) Striatal N-methyl-D-aspartate receptors in haloperidol-induced catalepsy. Eur J Pharmacol 203:173-180 